\title{
Manajemen Stres Istri yang Melangsungkan Pernikahan Dini
}

\author{
Cut Intan Fitria', ${ }^{1}$ usmami ${ }^{2}$, Marimbun $^{3}$ \\ Bimbingan dan Konseling Islam, Fakultas Ushuluddin Adab dan Dakwah, IAIN Langsa, Indonesia 1,2,3 \\ dzakiahasby@gmail.com
}

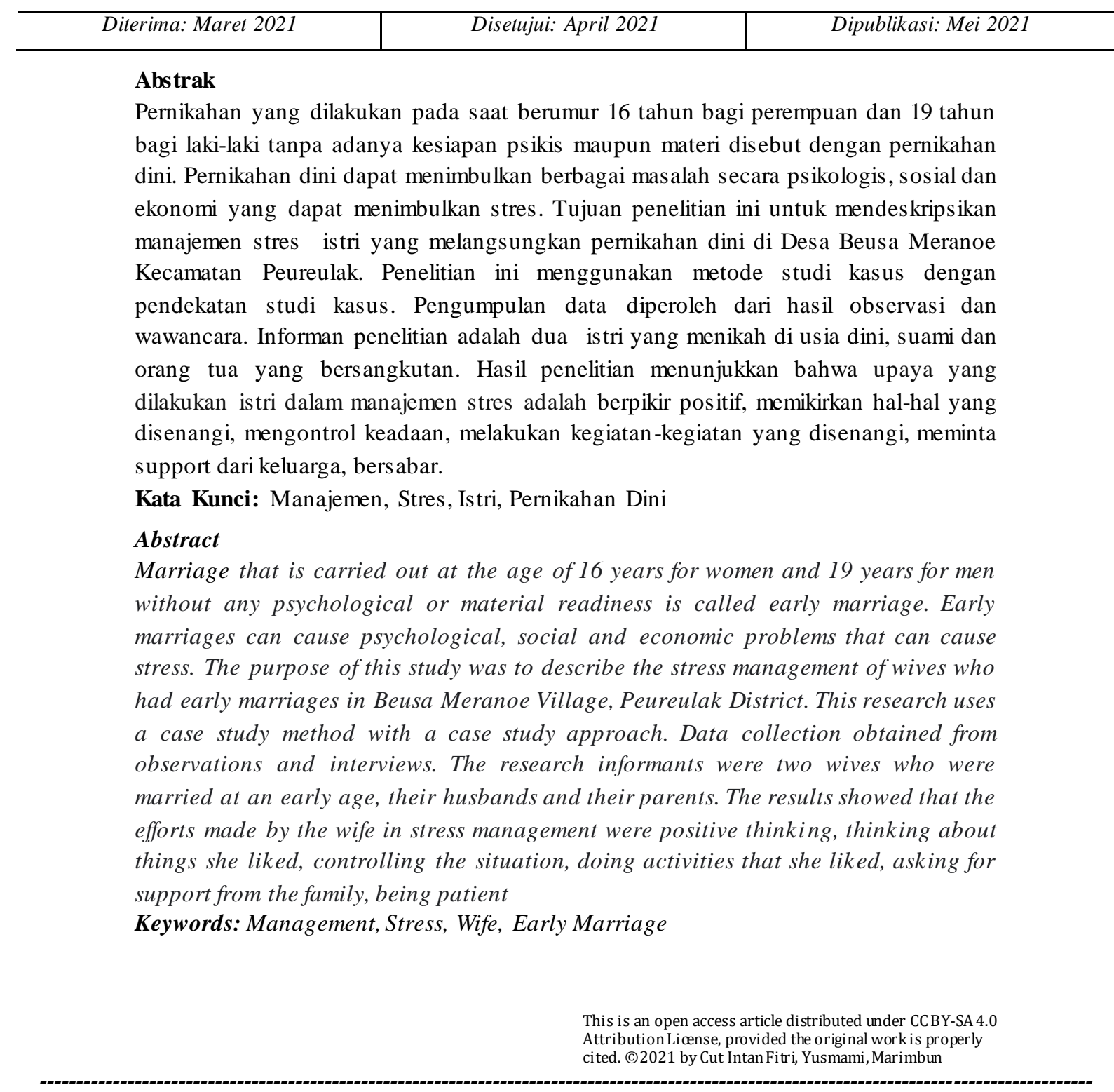

\section{PENDAHULUAN}

Pernikahan merupakan anjuran agama untuk melakukan ikatan dalam sebuah keluarga baru. Secara filosofis, menikah atau berpasangan merupakan ciri dari makhluk hidup (Sarwat, 2009). Pernikahan menjadi pintu utama untuk melanjutkan keturunan. Pernikahan akan membuat individu menjalani proses kehidupan dengan seimbang antara biologis, psiokologis maupun social (Wulanuari, Napida A, \& Suparman, 2017) 
Pernikahan membutuhkan persiapan yang matang, baik secara fisik maupun psikis. Undang-Undang No. 1 Tahun 1974 tentang Perkawinan Pasal 7 Ayat 1 bahwa "Perkawinan hanya diizinkan bila pihak pria mencapai umur 19 (sembilan belas) tahun dan pihak wanita sudah mencapai usia 16 (enam belas) tahun. Senada dengan itu, Peraturan Menteri Agama Republik Indonesia No. 11 Tahun 2007 tentang Pencatatan Nikah Pasal 8 dijelaskan bahwa "Apabila seorang calon suami belum mencapai umur 19 (sembilan belas) tahun dan calon istri belum mencapai umur 18 (delapan belas) tahun, harus mendapat dispensasi dari pengadilan". Pasangan yang menikah di usia 19 tahun umur laki- laki dan perempuan 16 tahun maka pernikahan tersebut bisa dinamakan dengan pernikahan dini. Secara psikologis belum siap untuk menjalani kehidupan rumah tangga. Oleh karena itu, Peraturan Menteri Agama Republik Indonesia No. 11 Tahun 2007 tentang Pencatatan Nikah Pasal 7 juga telah menjelaskan bahwa "Apabila seorang calon mempelai belum mencapai umur 21 (dua puluh satu) tahun, harus mendapat izin tertulis kedua orang tua". Izin ini sifatnya wajib, karena usia itu dipandang masih memerlukan bimbingan dan pengawasan orang tua (Yendi, Ardi, \& Ifdil, 2017).

Laki-laki dan peremuan lebih dianjurkan menikah disaat usianya sudah matang (dewasa). Walaupun demikian, dalam diskursus fiqih tidak membatasi usia nikah. Para fuqaha hanya menyatakan bahwa ukuran perempuan untuk menikah adalah kemampuannya serta kesiapannya untuk aktivitas seksual (wath'iy) serta segala konsekuensinya, seperti mengandung, melahirkan, dan menyusui, membesarkan anak yang kesemuannya ditandai dengan masa pubertas (Hanafi, 2011). Kenyataanya masih banyak para calon mempelai atau bahkan suami istri melaksanakan pernikahan dibawah umur. Menurut Rumekti (2016), pernikahan dini adalah pernikahan yang dilakukan oleh remaja pada saat berumur 16 tahun bagi perempuan dan 19 tahun bagi laki-laki tanpa adanya kesiapan psikis maupun materi. Menurut Romauli \& Vindari (2012), bahwa pernikahan dini merupakan perkawinan yang berlangsung pada usia remaja. Pernikahan yang dilaksanakan di usia remaja akan berpotensi lebih besar menimbulkan masalah secara psikologis, sosial dan ekonomi (Desiyanti, 2015).

Pernikahan dini dapat berdampak kepada hal- hal negatif kepada masa depan perempuan, kerena pernikahan dini membatasi aktivitas perempuan, kehilangan kesempatan untuk melakukan berbagai hal yang dapat dilakukan pada usia muda (Fathur \& Alfa, 2019). Pernikahan dini dapat menimbulkan berbagai masalah termasuk pendidikan, ekonomi, dan kesehatan reproduksi. (Sudarto, 2014). Fenomena pernikahan dini di ibaratkan gunung es yang tampak sebagian kecil di permukaan, sangat tetapi kenyataannya banyak terjadi di dalam masyarakat (Rifiani, 2011). Berdasarkan Survei Data Kependudukan Indonesia (SDKI) mengungkap bahwa masih banyak jumlah pernikahan dini yang terdata (Fadlyana \& Larasaty, 2009). Permasalahan pada pernikahan dini dikarenakan ketidakkesiapan pasangan dari aspek kesehatan, psikologis, sosial ekonomi, dan reproduksi.(Khairunnisa, Hidayati, \& Setiawan, 2016). Pasangan yang menikah di usia dini tidak mampu beradaptasi dengan dengan kondisi dan lingkungan barunya sehingga mengakibatkan stres (Nurjannah \& Khija, 2018).

Stres menjadi salah satu dampak pernikahan dini. Ketidaksiapan pasangan yang menikah di usia dini dalam menjalani kehidupan berumah tangga menjadi indikator 
munculnya stres. Pasangan muda terutama perempuan sering mengalami stres. Usia yang masih muda sejalan dengan pemikiran yang belum matang namun melakukan pernikahan. Pasangan yang menikah dini mengalami stres di saat mempunyai peran di keluarga barunya dan harus menjadi orang tua di usia muda. Pasangan muda cenderung mengalami stres (Nurjannah \& Khija, 2018). Hasil penelitian Rostianah (2014) tentang pengalaman hidup wanita yang menikah dini menjelaskan bahwa wanita yang menikah dini mempunyai aspek-aspek negatif yang dapat menimbulkan stres (Khairunnisa et al., 2016). Pasangan remaja sering mengambil keputusan pada saat emosi setelah mengalami permasalahan yang dapat menimbulkan stres (Nurjannah \& Khija, 2018).

Stres merupakan kondisi yang menimbulkan tekanan dengan adanya tuntutan situasi yang menjadi beban yang diluar batas kemampuan individu untuk melaksanakan tuntutan tersebut. Apabila stres tidak diselesaikan dengan baik dapat berdampak pada kesehatan jiwa (Litiloly \& Swastiningsih, 2014). Manajemen stres merupakan usaha dalam menyelesaikan stres serta menghilangkan dampak negative. Oleh karena itu. Manajemen stres merupakan kemampuan individu dalam mengelola stres yang timbul dalam kehidupan sehari-hari (Litiloly \& Swastiningsih, 2014). Berdasarkan keseluruhan data di Desa Beusa Meranoe, terdapat pasangan yang melakukan pernikahan dini. Artinya, Fenomena di lapangan masih terdapat pasangan yang melakukan pernikahan dini di Desa Beusa Meranoe Peureulak. Berdasarkan hasil observasi pasangan melakukan pernikahan dini dikarenakan dijodohkan oleh kedua orang tuanya. Kedua pasangan ini sudah memiliki hubungan yang dekat sejak SMP. Oleh karena itu, perjodohan yang dilakukan oleh orang tua keduanya bukanlah karena keinginan orang tua semata, melainkan karena hubungan keduanya sudah sangat dekat dan dikhawatirkan akan terjadi perbuatan maksiat, maka kedua orang tua mereka memutuskan untuk menikahkan keduanya di usia muda.

Dari fenomena tersebut, maka peneliti tertarik untuk melakukan penelitian terkait dengan Manajemen Stres Istri yang Melangsungkan Pernikahan Dini Di Desa Beusa Meranoe Kecamatan Peureulak

\section{METODE}

Metode yang digunakan pada penelitian ini adalah kualitatif dengan jenis deskriptif penelitian studi kasus. Penelitian ini dilakukan di Desa Meranoe Kecamatan Peureulak Kabupaten Aceh Timur. Informan penelitian adalah istri yang menikah pada usia dini, suami, dan pihak keluarga. Penentuan informan dilakukan dengan purposive sampling. Teknik pengumpulan data dilakukan dengan observasi dan wawancara. Adapun tahapan analisis data yang dilakukan adalah mereduksi data, menyajikan dan menarik kesimpulan. Pengecekan keabsahan data dilakukan dengan triangulasi.

\section{HASIL TEMUAN}

Subjek penelitian adalah istri yang menikah pada usia dini yang bernama Yuliza (Nama Samaran). Yuliza menikah pada usia 16 tahun dengan alasan pernikahan adalah untuk menghindari dari pergaulan bebas atau dosa. Hasil Wawancara dengan Yuliza "Saya menikah pada usia 16 tahun.... support dari orang tua agar saya tidak terjerumus kedalam pergaulan bebas" (Wawancara/ 1 Oktober-2020). Senada dengan itu, orang tua Yuliza 
juga menyampaikan "agar tidak terjerumus ke dalam pergaulan yang salah, seperti yang kita lihat bahwa kebanyakan saat ini anak-anak sudah mulai pacar-pacaran, boncengboncengan, pegangan tangan, pelukan ketika berkendaraan dan lain sebagainya (Wawancara/ 3 Oktober-2020). Pernikahan dini mendapatkan restu dari kedua orang tua dua belah pihak. Salah satu alasan yang membuat orang tuanya mengizinkan karena khawatir dengan pergaulan anak muda zaman sekarang.

Pernikahan membuat suami istri mempunyai kewajiban masing- masing, tentu akan berbeda sebelum melangsungkan pernikahan. Hal ini juga disampaikan oleh Yuliza bahwa setelah menikah mendapatkan tanggungjawab untuk mengurus keperluan suami dan mempunyai pekerjaan rumah seperti cuci piring, memasak, merapikan rumah, mempersiapkan pakaian suami dan lain sebagainya. Keadaan seperti ini kadang membuat istri yang menikah dalam usia dini merasa tertekan karena belum mampu menyesuaikan diri dengan perbedaan sebelum dan setelah menikah. Sebelum menikah remaja bebas melakukan berbagai kegiatan dan aktivitas dengan teman- teman, namun setelah menikah perasaannya mudah bosan terutama karena belum terbiasa dengan situasi baru yang dihadapi. Ada beberapa kendala yang dialami oleh Yuliza seperti penyesuaian diri, kesiapan mental, dan kekurangan kesabaran terutama dalam finansial. Berdasarkan hasil wawancara dengan Yuliza "setelah menikah yang saya rasakan adalah finansial, karena suami belum memilki pekerjaan tetap, kemudian kesiapan mental dan penyesuaian diri dengan pasangan yang masih terasa sulit" (Wawancara/ 6 Oktober-2020). Yuliza mengaku sering bertengkar karena tidak bisa mengontrol emosi dan kurang nyaman dengan keadaan saat ini terutama karena kekurangan finansial.

Yuliza salah satu perempuan yang melakukan pernikahan dini dengan alasan pencegahan agar tidak terjerumus ke dalam pergaulan bebas, setelah melangsungkan pernikahan Yuliza mengalami stres karena situasi baru yang di alaminya, beberapa hal yang membuat stres adalah keadaan finansial, kesiapan mental, pertengkaran dalam rumah tangga dan lainnya. Ketika Yuliza stres membuat kondisi moodnya naik turun, kadang marah-marah dengan alasan yang tidak jelas. Ananda (nama samaran) juga salah satu yang melakukan pernikahan dini dengan alasan yang sama dengan Yuliza yaitu agar tidak terjerumus ke dalam pergaulan yang salah, setelah melakukan pernikahan dini dia berusaha untuk beradaptasi dengan keadaan baru dan mengalami stress karena keadaan ekonomi keluarganya. Stres yang dialami membuat perubahan dalam dirinya seperti perubahan mood, emosi yang tidak teratur dan lainnya, untuk mengatasi hal tersebut dia berusaha untuk memanajemen stresnya dengan cara berusaha menguasai keadaan, jangan sampai stress yang menguasinya, Hal itu dapat dilakukan dengan memperbanyak kegiatankegiatan positif. Untuk mengurangi rasa stress Ananda selalu berbagi kisah dengan orangorang terdekatnya. selanjutnya untuk mencegah stress dia juga mencari informasi terkait serta mengaplikasikannya, adapun peran suaminya dalam menangani stress yang dialami adalah sebagai support Julia.

Banyak dampak negatif yang dialami oleh pasangan yang melakukan pernikahan dini, salah satunya adalah mengalami stress. Beberapa tekanan yang menyebabkan stress termasuk kebutuhan keluarga, masalah pekerjaan, masalah kesehatan, dan hubungan social. Melalui wawancara dengan Yuliza "saya mengalami stres pernikahan, hal paling 
utama yang membuat saya stres adalah masalah ekonomi... ekonomi kami sangat paspasan bahkan bisa dibilang kurang dari cukup, karena suami saya yang belum memiliki pekerjaan tetap" (Wawancara/ 10 Oktober-2020). Senada dengan itu, hal yang membuat stress disampaikan oleh Ananda ".masalah finansial atau perekonomian keluarga, terkadang cukup terkadang tidak cukup dan masalah ini adalah masalah yang paling berat yang saya alami setelah pernikahan" (Wawancara/ 12 Oktober-2020). Hal yang sama yang disampaikan oleh orang tua Yuliza "anak saya stres sebagaimana cerita yang dia sampaikan adalah masalah finansial" (Wawancara/ 13 Oktober-2020). Masalah- masalah dalam keluarga membuat pasangan muda mengalami stres mengakibatkan pertengkaran dalam rumah tangga. Hasil wawancara dengan Ananda"saya dan suami belum bisa menahan dan menguasai emosi secara baik, jadi terkadang terjadi pertengkaranpertengkaran dalam rumah tangga saya" (Wawancara/ 12 Oktober-2020). Masalah dalam rumah tangga tentu belum pernah dialami sebelum menikah sehingga masih belum mampu menyikapi persoalan- persoalan dengan dewasa. Hal ini juga disampaikan oleh Ananda "cepat marah, mood yang naik turun, kadang marah-marah tidak jelas". (Wawancara/ 12 Oktober-2020).

Reaksi saat stres akan mudah terbawa emosi, tidak mau makan, dan malas beraktivitas. Hal ini disampaikan oleh suami Yuliza”sudah pasti rasa stress mengganggu aktivitas, bisa kadang sedang lapar tiba-tiba hilang, kadang-kadang lapar tapi tidak mood untuk makan, malas beraktivitas"(Wawancara/ 14 Oktober-2020). Untuk meminimalisir stres yang dilakukan oleh Yuliza adalah jalan- jalan sore, mengobrol dengan tetangga, media social, melihat aplikasi jual beli online, bersenda gurau. Wawancara dengan Yuliza "agar saya bisa tertawa dan senang saya biasanya jalan-jalan sore bersama suami, bercanda, mengobrol dengan tetangga, bermain sosial media, melihat-lihat aplikasi jual beli online dan banyak hal lainnya." (Wawancara/ 14 Oktober-2020), berbeda dengan Ananda yang menghibur diri dengan buah hatinya "saya bisa tertawa adalah buah hati saya yaitu anak saya, melihat dia tertawa membuat saya ikut tertawa dan senang"(Wawancara/ 15 Oktober-2020).

Manajemen stres merupakan salah satu usaha atau kemampuan individu dalam mengelola stress. Beberapa Manajemen stres yang dilakukan oleh Yuliza adalah berpikir positif, memikirkan hal-hal yang disenangi, mengontrol keadaan, melakukan kegiatankegiatan yang disenangi, meminta support dari keluarga, bersabar. Hal ini diketahui dari hasil wawancara dengan Yuliza "saya berusaha untuk mengendalikannya seperti berpikir positif, memikirkan hal-hal yang saya senangi”(Wawancara/ 17 Oktober 2020). Selanjutnya ditambahkan oleh Ibu Yuliza "dalam me manajemen stres adalah dengan memperhatikan diri sendiri melakukan apa yang disenangi dan mengontrol keadaan agar dia tidak dikuasai stress"(Wawancara/ 18 Oktober 2020). Hasil wawancara dengan Ananda "memperhatikan diri sendiri, meminta suport dari keluarga terdekat seperti suami dan orang tua, memikirkan hal-hal positif, sabar, dan lainnya” (Wawancara/ 19 Oktober2020). Selanjutnya, Yuliza sering menghibur diri sendiri, meceritakan berbagai masalahnya kepada Ibunya dan suaminya. 


\section{PEMBAHASAN}

Pernikahan adalah ikatan lahir batin antara seorang pria dengan seorang wanita sebagai seorang suami istri dengan tujuan membentuk keluarga yang bahagia dan kekal. Mengacu kepada Undang- undang perkawinan bahwa pernikahan hanya diijinkan apabila laki- laki sudah mencapai umur 19 tahun dan perempuan sudah mencapai umur 16 tahun. Kebijakan tentang usia minimal tentu sudah berbagai pertimbangan. Termasuk agar kedua belah pihak matang dari aspek fisik, psikis. Bagi yang melangsungkan pernikahan belum mencapai usia 21 tahun harus mendapat ijin dari kedua orang tuanya. Namun dalam prakteknya di masyarakat secara umum masih banyak yang melangsungkan pernikahan di usia muda atau di bawah umur. (Rifiani, 2011). Pernikahan dini merupakan perkawinan pada usia remaja (Romauli \& Vindari, 2012). Pernikahan dini merupakan pernikahan pada saat berumur 16 tahun bagi perempuan dan 19 tahun bagi laki-laki tanpa adanya kesiapan psikis maupun materi yang belum bisa dipenuhi (Rumekti, 2016). Pasangan remaja sering mengambil keputusan pada saat emosi setelah mengalami permasalahan yang dapat menimbulkan stres (Nurjannah \& Khija, 2018). Stres merupakan kondisi yang menimbulkan tekanan dengan adanya tuntutan situasi yang menjadi beban yang diluar batas kemampuan individu untuk melaksanakan tuntutan tersebut. Apabila stres tidak diselesaikan dengan baik dapat berdampak pada kesehatan jiwa (Litiloly \& Swastiningsih, 2014).

Manajemen stres merupakan kemampuan individu dalam mengatasi berbagai permasalah yang dapat menimbulkan stres (Rahmanida, 2011). Manajemen stres merupakan usaha untuk mengelola stres yang dapat membahayakan individu dalam kehidupan sehari-hari. Mumpuni dan Wulandari (2010), menyatakan stres harus diselesaikan dengan benar supaya tidak mengakibatkan hal yang lebih buruk. Beberapa cara dalam mengatasi stres yaitu: 1), menyelesaikan masalah. 2), mendekatkan diri kepada Tuhan. 3), bekerja dalam porsi wajar. 4), keseimbangan antara lahir batin dan dunia akhirat. 5), Silaturahmi. 6), mengenali penyebab terjadinya stres. 7), menyalurkan emosi. 8), perencanaan yang baik. 9), menjaga kesehatan.

\section{SIMPULAN}

Pernikahan dini merupakan pernikahan pada saat berumur 16 tahun bagi perempuan dan 19 tahun bagi laki-laki tanpa adanya kesiapan psikis maupun materi yang belum bisa dipenuhi. Pasangan remaja sering mengambil keputusan pada saat emosi setelah mengalami permasalahan yang dapat menimbulkan stres. Upaya yang istri melangsungkan pernikahan dini dalam manajemen stres adalah berpikir positif, memikirkan hal-hal yang disenangi, mengontrol keadaan, melakukan kegiatan-kegiatan yang disenangi, meminta support dari keluarga, dan bersabar. 


\section{DAFTAR PUSTAKA}

Desiyanti, I. W. (2015). Faktor-faktor yang berhubungan terhadap pernikahan dini pada pasangan usia subur di Kecamatan Mapanget Kota Manado. Jikmu, 5(3).

Fadlyana, E., \& Larasaty, S. (2009). Pernikahan Usia Dini dan Permasalahannya. Sari Pediatri, 11(2), 136-140. https://doi.org/10.14238/sp11.2.2009.136-41

Fathur, R., \& Alfa. (2019). Pernikahan Dini dan Perceraian di Indonesia. In Jurnal Ilmiah Ahwal Syakhshiyyah (JAS) (Vol. 1). Retrieved from http//riset.unisma.ac.id/index.php/fai/index

Hanafi, Y. (2011). Kontroversi Pernikahan Anak Di Bawah Umur. Bandung: Mandar Maju.

Khairunnisa, D., Hidayati, N. O., \& Setiawan. (2016). Tingkat Stress pada remaja wanita yang menikah dini di kecamatan babakancikao kabupaten purwakarta. Jurnal Ilmu Keperawatan, 4(2).

Litiloly, F., \& Swastiningsih, N. (2014). Manajemen Stres Pada Istri Yang Mengalami Long Distance Marriage. EMPATHY Jurnal Fakultas Psikologi, 2(2), 53-61.

Mumpuni, \& Wulandari. (2010). Cara Jitu Mengatasi Jerawat. Jogyakarta.

Nurjannah, S., \& Khija, Y. F. La. (2018). Pengalaman Wanita Menikah Dini Yang Berakhir Dengan Perceraian. Empati, 7(2), 136-148.

Rahmanida, E. (2011). Manajemen Stres Istri yang ditinggal Suaminya Bekerja di Luar Negeri. Universitas Muhammadiah Malang.

Rifiani, D. (2011). Pernikahan dini dalam perspektif hukum islam. Journal de Jure, 3(2).

Romauli, S., \& Vindari, A. (2012). Kesehatan Reproduksi buat Mahasiswi Kebidanan. Yogyakarta: Nuha Medika.

Romauli, S., \& Vindari, A. V. (2012). Kesehatan Reproduksi buat Mahasiswi Kebidanan. Yogyakarta: Nuha Medika.

Rostiana, A. (2014). Pengalaman Hidup Perempuan Yang Mengalami Pernikahan Usia Dini Di Desa Cikeusal Kecamatan Cimahi Kabupaten Kuningan. UNPAD.

Rumekti, M. M. (2016). Peran Pemerintah Daerah (Desa) Dalam Menangani Maraknya Fenomena Pernikahan Dini Di Desa Plosokerep Kabupaten Indramayu. E-Societas, $5(6)$. 
Sarwat, A. (2009). Fiqih Nikah. Jakarta: Kampus Syariah.

Sudarto, A. (2014). Studi Deskriptif Kepuasan Perkawinan pada Perempuan yang Menikah Dini. Calyptra: Jurnal Ilmiah Mahasiswa Universitas Surabaya, 3(1).

Wulanuari, K. A., Napida A, A., \& Suparman. (2017). Faktor-Faktor yang Berhubungan dengan Pernikahan Dini pada Wanita. Jurnal Ners Dan Kebidanan Indonesia, 5(1), $68-75$.

Yendi, F. M., Ardi, Z., \& Ifdil, I. (2017). How to Prepare the Marriage?; The Brief Counseling Approach. The Responsibility of Counselor and Educator in Millennium Era, 119-124. https://doi.org/10.31219/osf.io/rdq97 